\title{
Sintering behaviour of ceramic bodies from contaminated marine sediments
}

\author{
M. Romero ${ }^{\mathrm{a},{ }^{*},}$ A. Andrés ${ }^{\mathrm{b}}$, R. Alonso ${ }^{\mathrm{b}}$, J. Viguri $^{\mathrm{b}}$, J.Ma. Rincón ${ }^{\mathrm{a}}$ \\ a Group of Glassy and Ceramic Materials. Department of Building Construction \\ Systems. Institute of Construction Sciences "Eduardo Torroja"-CSIC. C/ Serrano \\ Galvache, 4. 28033 Madrid, Spain. \\ b Department of Chemical Engineering and Inorganic Chemistry. University of \\ Cantabria. Avda. Los Castros s/n. 39005 Santander, Spain.
}
* Corresponding author. Tel./fax: 34913020440 / 34913020700 e-mail address: mromero@ietcc.csic.es

\begin{abstract}
The effect of the heating temperature on the properties of sintered ceramic bodies from three different contaminated marine sediments was investigated. The sintering behaviour was evaluated by means of the variation of shrinkage degree, bulk density, water absorption, open and closed porosity, while the phases transformation were investigated by differential thermal analysis (DTA), X-ray diffraction (XRD) and scanning electron microscopy (SEM). The results have shown that the sintering process follows a viscous liquid phase mechanism due to the formation of a glassy phase. The optimum sintering temperature is $1125^{\circ} \mathrm{C}$ for Astilleros and Cuchia sediments and $1150^{\circ} \mathrm{C}$ for Raos sample. Above this temperature, a significant overfiring with an increase of closed porosity was observed. Water absorption values and mechanical properties as bending and compressive strengths of sintered bodies show that the investigated marine sediments are suitable to be used as secondary raw materials in ceramic tiles and bricks production.
\end{abstract}

Keywords: A. Sintering; B. Electron microscopy; D. Traditional ceramics; Marine sediments

\section{Introduction}

Marine sediments are deposited material consisting of insoluble material, primarily rock and soil particles transported from land areas to the ocean, organic matter in various stages of decomposition and remains of marine organisms that accumulate on the seafloor. Marine sediments vary widely in composition and physical characteristics as a function of water depth, distance from land, variations in sediment source, and the physical, chemical, and biological characteristics of their environments.

Due to the exposure to industrials effluents, sediments constitute a pollutant tramp and may contain high levels of pollutant. Indeed, marine sediments are normally utilized as indicators to identify environmental impacts [1-3]. Once the potential risks of contaminated sediments have been assessed by tiered ecological risk assessment frameworks, it would be necessary remediation actions including dredging [4]. On the 
other hand, dredging actions are necessary to allow all the uses of a water system. In both cases, a sustainable process of dredged material management will be applied. Since dredged material may be contaminated, it will be necessary to carry out a characterization to decide the most suitable destination for the material [5]. In this context, the Action Levels (ALs) have been established as numerical criteria of dredged material management that define different classes of dredged material, and each class is associated with a destination or management. The options in dredged material management, depending on the legal framework [6, 7], are re-collocation in the water system, beneficial use, treatment and confined disposal.

Sediments from Santander and Suances Cantabrian estuaries (Northern Spain) have been previously characterised by different chemical and ecotoxicological parameters in order to study the pollution of these coastal areas. Sediments from both estuaries contain significant concentrations of heavy metals and organic pollutants derived from intensive industrial, agricultural and urban activities, making necessary treatment and confined disposal to manage them properly [8-11].

The valorisation of wastes as secondary raw materials in the production of construction materials could allay the problems associated to both, the depletion of natural resources and the disposal of industrial wastes. Among construction materials, traditional claybased materials are heterogeneous products that can accommodate different inorganic wastes or sub-products without modification of its production process or the final product properties [12-14]. Consequently, the incorporation of industrial wastes or subproducts in bricks and tiles is becoming a frequent practice in the ceramic factories. In this sense, it has been conducted several studies in last years concerning the production of bricks with the incorporation of both organic [15-17] and inorganic wastes, such as, sewage sludge ash [18-20], waterworks sludge [21], natural stone wastes [22-26], fly and bottom ashes [27-34], metallurgical wastes [35-38] and boron waste [39, 40].

These investigations, focused in the development of clay/waste mixtures in order to obtain marketable ceramics materials, have shown same benefits as, i) saving of resource, raw material and energy; ii) positive effects on the brick-making process; iii) improving final product quality; iv) reducing the cost of final product due to using waste additive in the process.

Marine sediments can be use as clay replacement in ceramic processes to obtain a building material. During the sintering process, organic contaminants are oxidized and metal contaminants are either converted to stable immobile compounds or volatilized. Harbour sediments are suitable for light weight aggregates production, obtaining a construction material that is not hazardous during its whole life cycle [41]. Dredged material has been used as a suitable raw material in the production of ceramics materials that fulfil the physical requirements of constructional standards [42-44].

Anyway, the main factors that determine the applicability of ceramic technology are the properties of the sediments and the possibilities for using the end-products as building materials. In this sense it is essential to understand sediment characteristics and evaluate 
the feasibility of treating the dredged material under a site-specific framework. The aim of this work is to evaluate the suitability of marine sediments with inorganic and organic contaminants as alternative raw materials in the manufacture of traditional clay based ceramic materials. For this, the sintering of three marine sediments following a conventional powder process has been studied in order to determine the effect of the varying heating temperature on bulk density, water absorption, porosity and mechanical properties of the sintered samples.

\section{Experimental procedure}

Samples of $20 \mathrm{~kg}$ of $50 \mathrm{~cm}$ polluted depth sediment were obtained from the estuary of Suances (Cuchia) and the bay of Santander (Astilleros and Raos) using a grab sampler [8]. All samples were homogenised and transferred in clean glass jars, capped with aluminium foil and kept in the dark at $4^{\circ} \mathrm{C}$ until analysis. Table I shows the chemical analysis determined by X-ray fluorescence. According to the XRF analyses, the three samples consists of $\mathrm{SiO}_{2}$ and $\mathrm{Al}_{2} \mathrm{O}_{3}$ as major components along with $\mathrm{Fe}_{2} \mathrm{O}_{3}$ as main constituent, in Astilleros sample, and $\mathrm{CaO}$, in Cuchia and Raos samples. All sediments present a significant loss of ignition (LOI) determined according to the DIN 38414-3 Standard [45], which is likely associated to carbonate and sulphate decomposition and also to burn-off of organic matter that is usually adsorbed in this kind of materials.

Table I. Chemical composition of the sediments, as determined by XRF (wt.\%)

\begin{tabular}{|c|c|c|c|}
\hline & Astilleros & Cuchia & Raos \\
\hline $\mathrm{SiO}_{2}$ & 47.13 & 53.54 & 57.26 \\
\hline $\mathbf{A l}_{2} \mathbf{O}_{3}$ & 11.73 & 8.43 & 7.69 \\
\hline $\mathrm{Fe}_{2} \mathrm{O}_{3}$ & 21.55 & 4.50 & 4.13 \\
\hline MnO & 0.31 & 0.03 & 0.05 \\
\hline MgO & 1.46 & 2.36 & 3.60 \\
\hline $\mathrm{CaO}$ & 1.41 & 7.48 & 6.81 \\
\hline $\mathrm{Na}_{2} \mathrm{O}$ & 1.08 & 1.51 & 1.23 \\
\hline $\mathbf{K}_{2} \mathbf{O}$ & 1.62 & 1.85 & 1.83 \\
\hline $\mathrm{TiO}_{2}$ & 0.63 & 0.55 & 0.57 \\
\hline $\mathbf{P}_{2} \mathbf{O}_{5}$ & 0.23 & 0.17 & 0.17 \\
\hline LOI & 12.01 & 19.35 & 16.69 \\
\hline
\end{tabular}

The as-received sediments were oven-dried at $105^{\circ} \mathrm{C}$ for $24 \mathrm{~h}$ and then crushed, grounded and finally powdered to $<160 \mu \mathrm{m}$ prior to their characterization and further use. 
The thermal behaviour was determined by Differential Thermal Analysis coupled with thermogravimetic analysis (Setaram Labsys equipment). DTA/TG test were recorded at a heating rate of $10^{\circ} \mathrm{C} / \mathrm{min}$, in platinum crucibles and air atmosphere. Calcined alumina was used as reference material. The mineralogical composition was determined by $\mathrm{X}$ ray diffraction analyses (Siemens D5000 diffractometer), using CuKa radiation and operating at $30 \mathrm{~mA}$ and $50 \mathrm{kV}$.

The powders were compacted at $40 \mathrm{MPa}$ to form disc-shaped specimens $(2.0 \mathrm{~cm}$ in diameter and $0.5 \mathrm{~cm}$ in height). Moreover, rectangular bodies of 50x10x8mm and squared bodies of 20x20 mm were pressed for bending strength and compressive strength measurements respectively. The compacted specimens were sintered in an electrically heated furnace at temperatures between $900^{\circ}$ and $1200^{\circ} \mathrm{C}$ by using a ramp rate of $15^{\circ} \mathrm{C} / \mathrm{min}$. The samples were hold at the maximum temperature for $1 \mathrm{~h}$ and then cooled inside the furnace at a rate of $50^{\circ} \mathrm{C} / \mathrm{min}$ down to $500^{\circ} \mathrm{C}$.

The shrinkage degree during the sintering process was determined by hot-stage microscopy (Misura 3.0 microscope) on small pressed specimens. The HSM measurements were carried out in air with a heating rate of $10^{\circ} \mathrm{C} / \mathrm{min}$. Images of the sample profile were taken at $10^{\circ} \mathrm{C}$ periods from room temperature to $1400^{\circ} \mathrm{C}$.

The sintering behaviour of the fired samples was evaluated on the basis of bulk density $\left(\mathrm{g} / \mathrm{cm}^{3}\right)$, open porosity (\%) and water absorption (\%), as required by ASTM C373, which involves boiling in water for $5 \mathrm{~h}$ and a further soaking of $24 \mathrm{~h}$ at room temperature.

The development of porosity was also evaluated by scanning electron microscopy (SEM, Jeol JSM 540) on the broken surface of sintered samples. SEM specimens were polished using 6, 3 and $1 \mu \mathrm{m}$ diamond pastes after grinding with silicon carbide paper and water. The polished surfaces were Au-Pd coated.

Finally, bending and compressive strength was measured in an electronic universal testing machine (Servosis) on 10 test specimens for each sintered temperature. Bending strength determination was carried out by a three-point loading test with a span of 36 $\mathrm{mm}$ and crosshead speed of $3 \mathrm{~mm} / \mathrm{min}$. For compressive strength the load had been applied uniformly with a speed of $15 \mathrm{~N} / \mathrm{s}$ through two stiff and flat hardened steel platens.

\section{Results and discussion}

\section{Characterization of marine sediments}

Figure 1 shows the X-ray diffraction patterns of the three marine sediments. It can be seen that all the samples contain quartz as major crystalline phase. Ca-containing phases as calcite $\left(\mathrm{CaCO}_{3}\right)$, anhydrite $\left(\mathrm{CaSO}_{4}\right)$ and dolomite $\left(\mathrm{CaMg}\left(\mathrm{CO}_{3}\right)_{2}\right)$ are detected in Cuchia and Raos samples, whereas $\mathrm{Mg}_{2} \mathrm{SiO}_{4}$ is also presents in Raos sediment with a great content in magnesium. As for Astilleros sample, its chemical composition shows a 
significant percentage of iron, which appears in the diffractogram as goethite $(\mathrm{FeO}(\mathrm{OH}))$. The crystalline phases identified by XRD are in agreement with the results obtained by XRF (Table I). According to their chemical and mineralogical composition, the three sediments are suitable to be used as secondary raw material in a traditional ceramic paste [46]. Indeed, most clays used for brick and roof tile production contain appreciable amounts of iron oxide and calcium oxide, which is usually present as $\mathrm{CaCO}_{3}$ and $\mathrm{CaMg}\left(\mathrm{CO}_{3}\right)_{2}$. Moreover, quartz is one of the main components in ceramic pastes. The only problem could be caused by the presence of anhydrite, which is a soluble salt that can cause efflorescence. Nevertheless, its effect can be palliated by adding an adequate efflorescence restraining additive, such as $\mathrm{BaCO}_{3}$ or $\mathrm{BaCl}$ [47]. On the other hand, since alkaline and alkaline-earth oxides are fluxing agents and promote vitrification, the addition of these sediments as secondary raw material to a ceramic paste will likely decrease the firing temperature, with the corresponding energy saving.
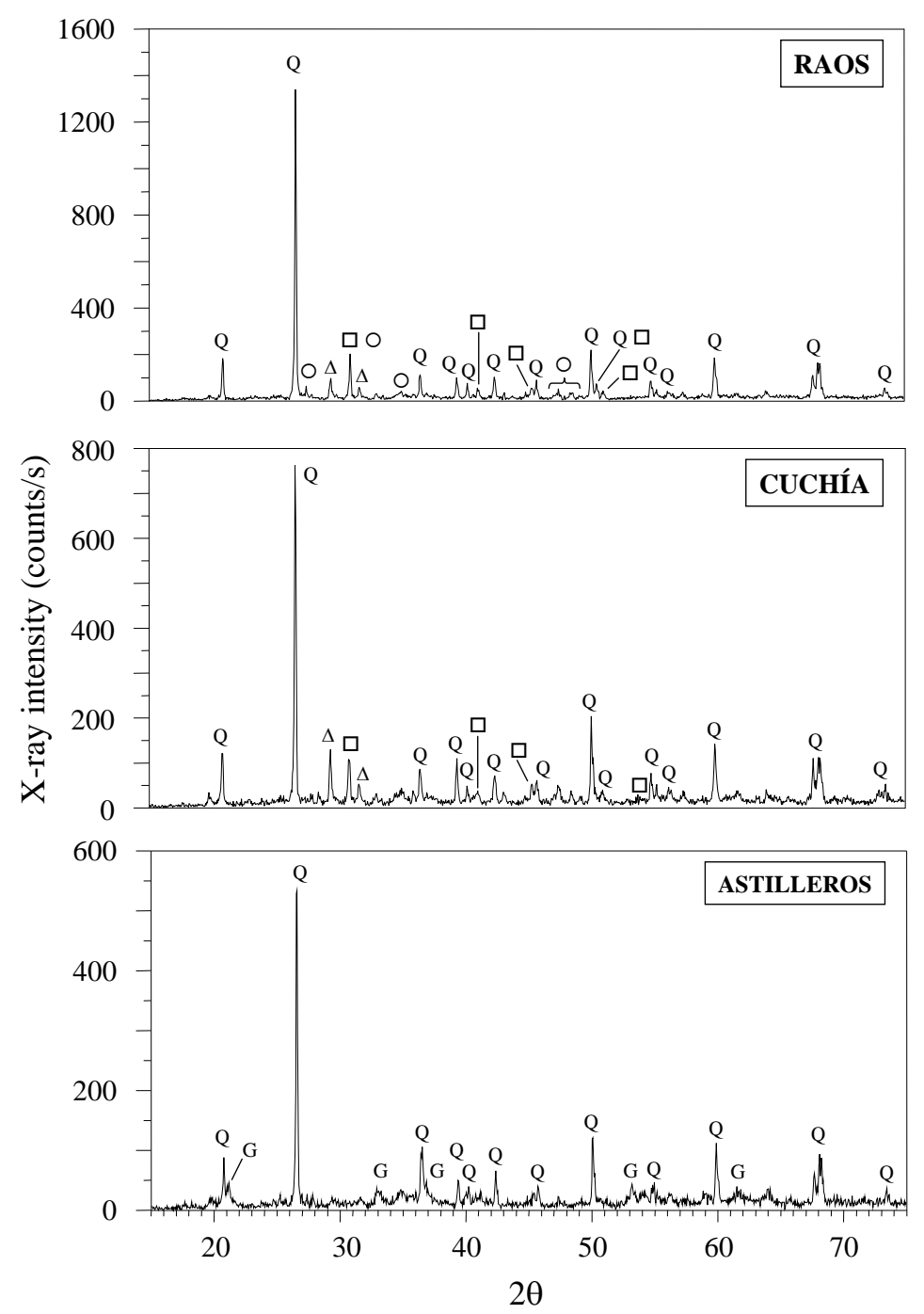

Figure 1. X-ray diffraction patterns from Astilleros, Cuchia and Raos sediments $(\mathrm{Q}=$ quartz; $\left.\mathrm{G}=\mathrm{FeO}(\mathrm{OH}) ; \square=\mathrm{CaMg}\left(\mathrm{CO}_{3}\right)_{2} ; \Delta=\mathrm{CaCO}_{3}, \mathrm{CaSO}_{4} ; \mathrm{O}=\mathrm{Mg}_{2} \mathrm{SiO}_{4}\right)$. 
In order to investigate the reactions taking place during the sintering process, the samples were studied in non-isothermal conditions by HSM and ATD/TG. Figure 2 plots the variation of shrinkage degree with temperature. There is no evidence of any volume change related to low temperature phase transformations. The densification in all the samples starts at $1100^{\circ}-1150^{\circ}$ and is followed by a volume increase, which is more evident in Astilleros sample, probably due to bubbles formation as result of volatile components losses. After that, the shrinkage strongly increases due to the formation of a liquid phase.

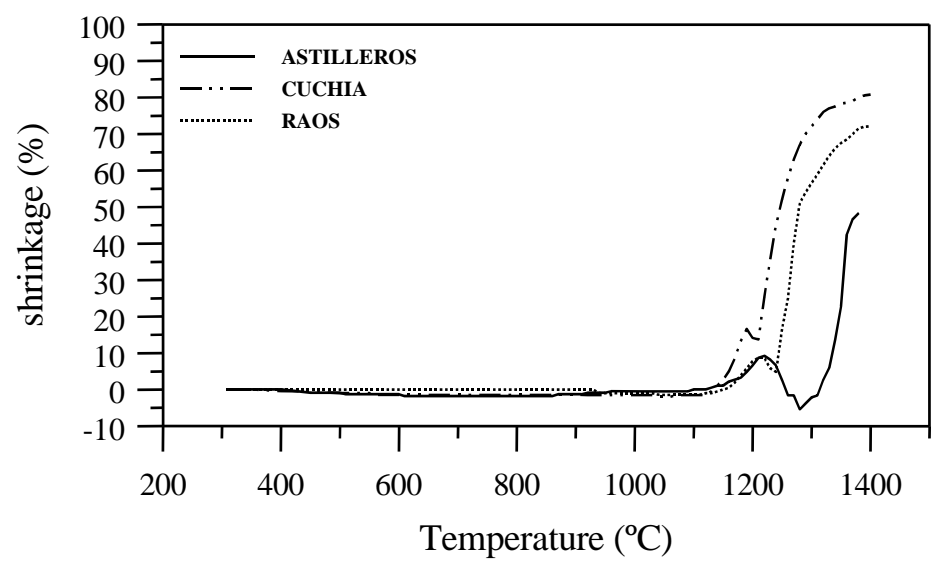

Figure 2. Variation of shrinkage degree with temperature for Astilleros, Cuchia and Raos sediments (determined by HSM).

Figure 3 depicts the DTA/TG curves. All samples show several exothermic effects in the $250^{\circ}-550^{\circ} \mathrm{C}$ interval, which are likely due to the oxidation of the organic matter adsorbed in the sediments [48]. The characteristic endothermic peak due to $\alpha \rightarrow \beta$ quartz inversion at $\approx 570^{\circ} \mathrm{C}$ is only detected in Raos sample with the biggest $\mathrm{SiO}_{2}$ content. Small endothermic peaks perceived in both Cuchia and Raos samples at $700^{\circ}-900^{\circ} \mathrm{C}$ are due to carbonate decomposition [49]. Finally, an endothermic effect over $1000^{\circ} \mathrm{C}$ indicates a liquid phase formation in agreement with HSM results. As for thermogravimetric analysis, TG curves exhibit weight losses slightly higher that those showed by LOI analyses, which is likely due to the higher temperature reached in TG experiments $\left(1200^{\circ} \mathrm{C}\right)$.

\section{Characterization of sintered samples}

The compacted samples were heat treated at different temperatures in the range $900^{\circ}$ $1200^{\circ} \mathrm{C}$ for $1 \mathrm{~h}$. The effect of heat treatment on sintering as observed by the naked eye is summarized in Table II.

Figure 4 plots the open porosity, water absorption and bulk density as function of firing temperature in the $1000^{\circ}-1150^{\circ} \mathrm{C}$ temperature range. Upon firing, all the measured properties show the typical trend of conventional clay based ceramic products. Figure clearly display differential changes in bulk density through the firing temperature. The 
bulk densities increase, reached a maximum value in Astilleros and Raos samples, and at higher temperatures decreases rapidly likely due to the increasing of closed porosity because of the so-called body bloating due to the pressure of the gas inside the closed pores, which tends to expand the pores. Open porosity decreases with increasing firing temperature indicating that the sintering process follows a viscous liquid phase mechanism due to the formation of a glassy phase [50]. Increasing temperatures causes both an increase in liquid phase amount and a decrease in liquid phase viscosity. Under the surface energy forces created by the fine pores contained in the ceramic body, the liquid phase trends to approach the particles and, therefore, open porosity decreases. Finally, since water absorption is directly related to open porosity, both properties show the same trend in the overall temperature range.

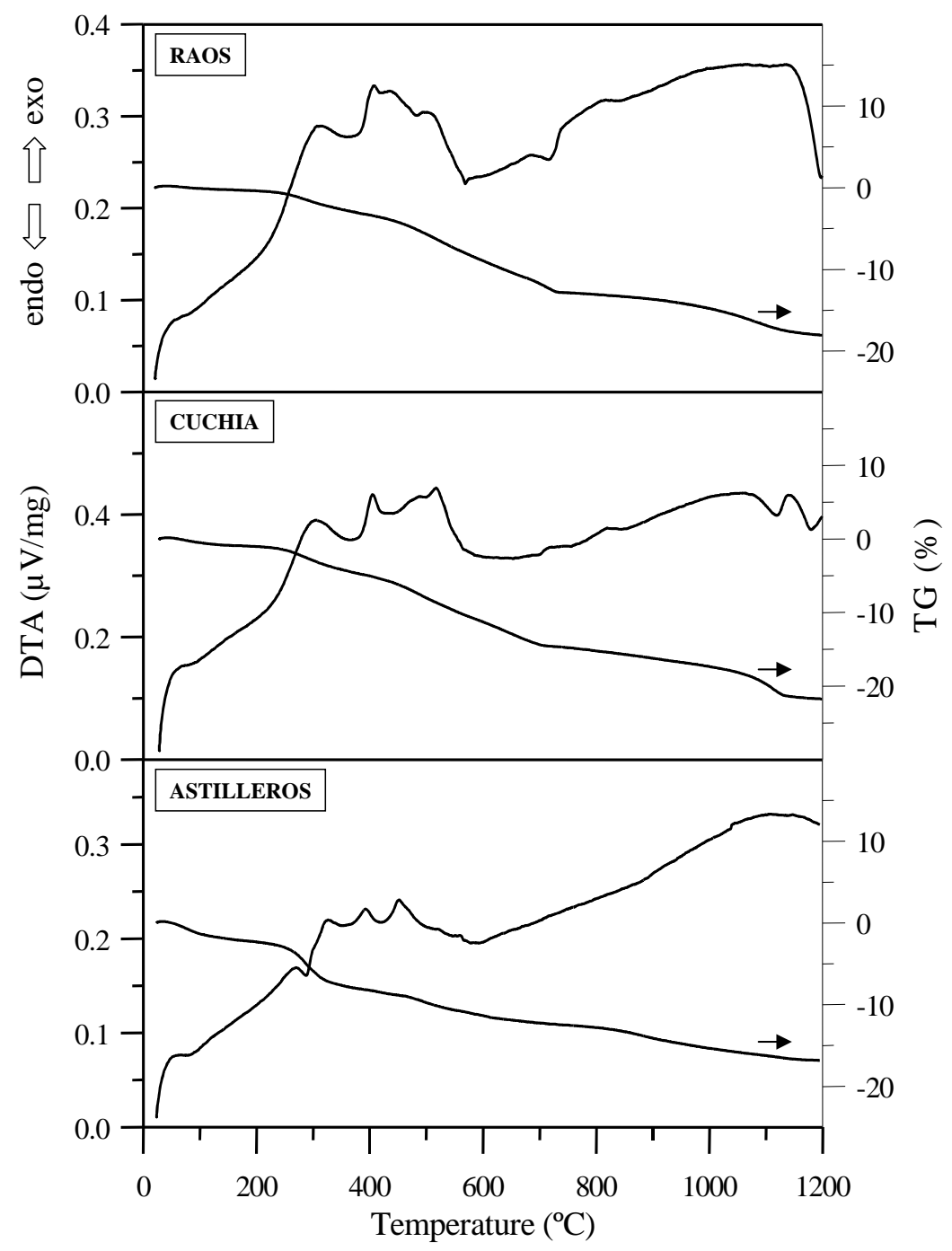

Figure 3. DTA/TG curves recorded from Astilleros, Cuchia and Raos sediments. 
Table II. Effect of heat treatment temperature on sintering of sediments compacts

\begin{tabular}{|c|c|c|}
\hline & Temperature $\left({ }^{\circ} \mathrm{C}\right)$ & Appearance \\
\hline \multirow{6}{*}{ Astilleros } & 900 & Low sintering \\
\hline & 1000 & High sintering. Without defects \\
\hline & 1050 & High sintering. Without defects \\
\hline & 1100 & High sintering. Without defects \\
\hline & 1125 & High sintering. Without defects \\
\hline & 1150 & High sintering. Small surface bubbles \\
\hline \multirow{5}{*}{ Cuchia } & 1000 & Low sintering \\
\hline & 1100 & High sintering. Without defects \\
\hline & 1115 & High sintering. Without defects \\
\hline & 1125 & High sintering. Without defects \\
\hline & 1150 & Softening \\
\hline \multirow{7}{*}{ Raos } & 1000 & Low sintering \\
\hline & 1050 & Low sintering \\
\hline & 1100 & Low sintering \\
\hline & 1115 & High sintering. Without defects \\
\hline & 1125 & High sintering. Without defects \\
\hline & 1150 & High sintering. Without defects \\
\hline & 1200 & Softening \\
\hline
\end{tabular}

The evolution of porosity with temperature has been also observed by SEM. Figures 5-7 show SEM observations on polished surfaces of sediments compacts fired at different temperatures in the $1000^{\circ}-1200^{\circ} \mathrm{C}$ range.

The three sediments show a similar trend of porosity versus firing temperature. At lower temperatures the porosity is mainly due to open porosity, which is formed by fine, interconnected and irregular shape pores. The occurrence of open porosity in the fired samples could be favoured by different causes, such as entrapped air in the ceramic slurry; formation of voids during the different drying steps; gases released in the thermal decomposition of carbonates and sulphates or even by the liberation of gases dissolved in quartz particles. As firing temperature increase, the capillary pressure due to the surface tension of the liquid phase tends to approach the particles, which in turn changes the porosity from open to closed porosity, which is formed by greater, isolated and spherical pores. At higher temperatures, the pressure of the gas inside the closed pores tends to expand the pores and closed porosity increases. 
M. Romero, A. Andrés, R. Alonso, J. Viguri, J.Ma. Rincón, Sintering behaviour of ceramic bodies from contaminated marine sediments, Ceramics International, 34 (2008) 1917-1924; doi: 10.1016/j.ceramint.2007.07.002

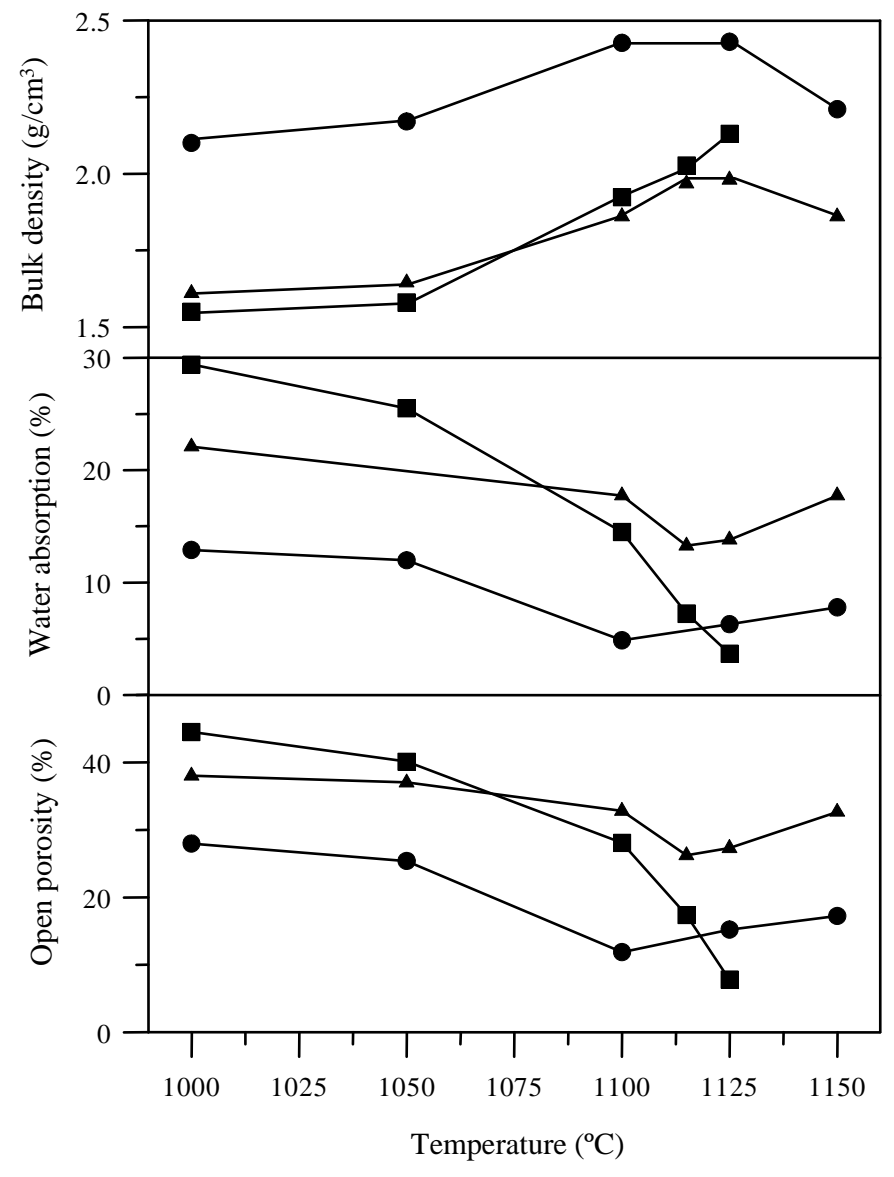

Figure 4. Bulk density, water absorption and open porosity, as function of firing temperature in the $1000^{\circ}-1150^{\circ} \mathrm{C}$ temperature range ( Astilleros; Cuchia; $\boldsymbol{\Delta}$ Raos).
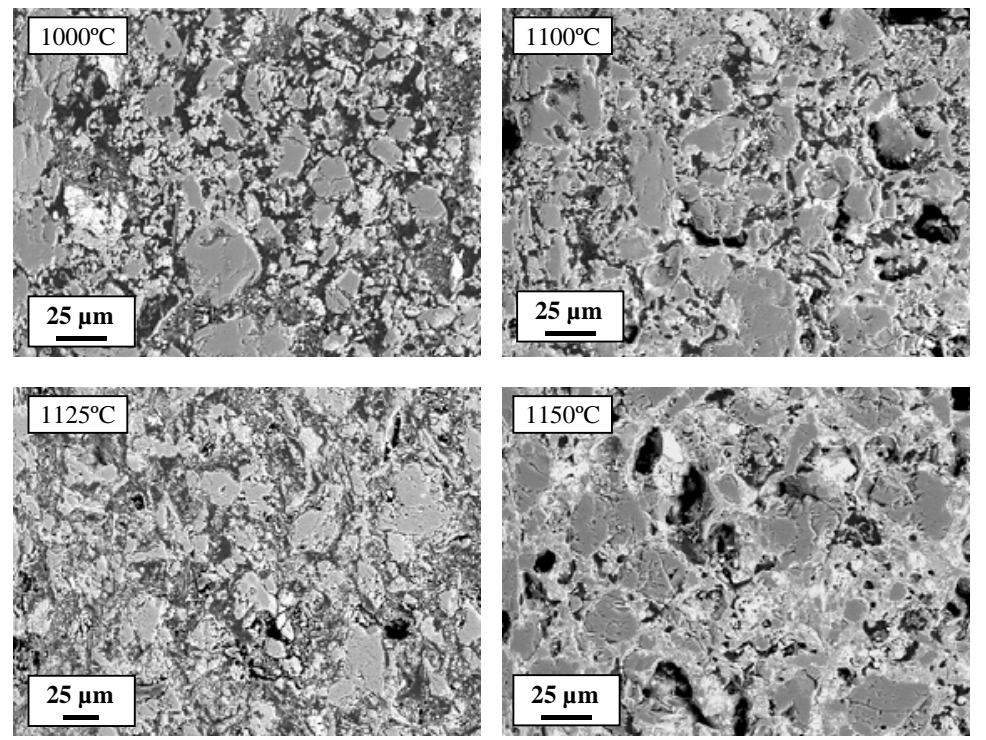

Figure 5. SEM observations on polished surfaces of Astilleros sediment compacts fired at different temperatures in the $1000^{\circ}-1150^{\circ} \mathrm{C}$ range. 

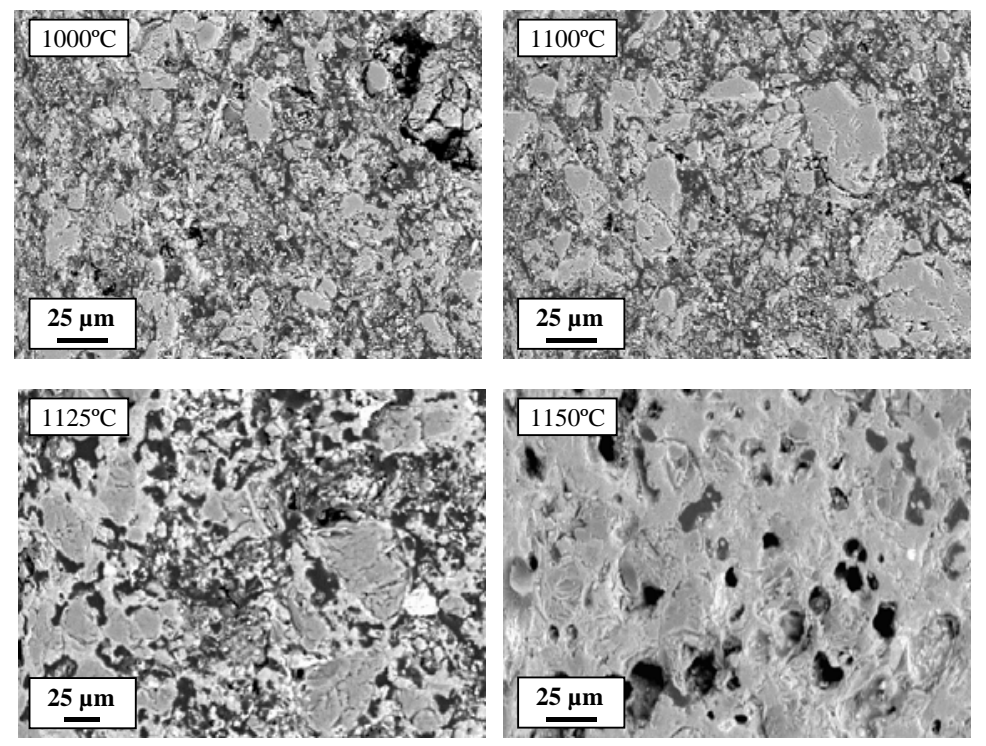

Figure 6. SEM observations on polished surfaces of Cuchia sediment compacts fired at different temperatures in the $1000^{\circ}-1125^{\circ} \mathrm{C}$ range.
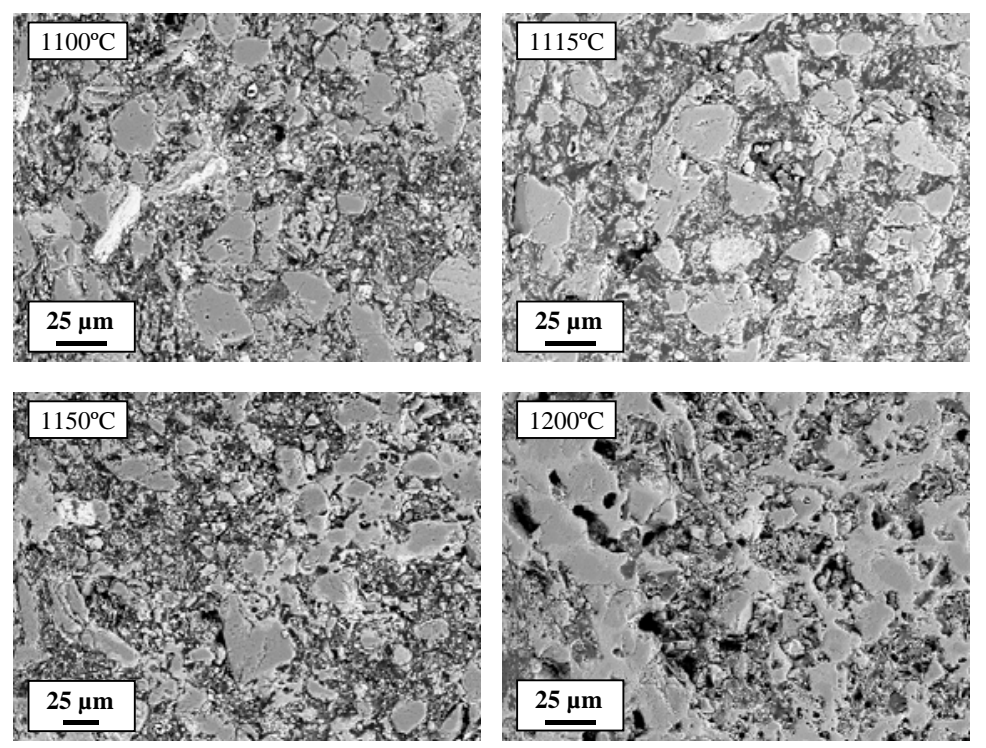

Figure 7. SEM observations on polished surfaces of Raos sediment compacts fired at different temperatures in the $1100^{\circ}-1200^{\circ} \mathrm{C}$ range.

The optimum sintering range is achieved when open porosity reaches a minimum value and simultaneously linear shrinkage is maxima. Firing at upper temperatures results in a drastic fall of the physical properties due to forced expulsion of the entrapped gases, resulting in blisters and bloating. From Table II and Figures 2 and 4-7 it can be established that the optimum sintering temperature is $1125^{\circ} \mathrm{C}$ for Astilleros and Cuchia sediments and $1150^{\circ} \mathrm{C}$ for Raos sample. At these temperatures, sintered bodies show water absorption values of $6 \%$ for Astilleros, $4 \%$ for Cuchia and $14 \%$ for Raos 
sediment. Astilleros and Cuchia specimens fulfil the requirements prescribed by AENOR (Spanish Association for Normalization and Standardization), which establishes water absorption values, as determined by the European Standard EN-771-1 Annex C [51], of $\leq 14 \%$ and $\leq 6 \%$ for high density traditional bricks and high density clinker bricks respectively. Those sintered sediments satisfy also the values specified by ASCER (Spanish Association of Ceramic Pavement and Covering Tiles), which establishes water absorption values, as determined by the European Standard EN ISO 10545-3 [52], of $11-15 \%$ and $\leq 6 \%$ for covering and pavement ceramic tiles respectively. As for Raos sample, its addition to a ceramic paste for clinker brick or pavement tile production, requires a previous study to determine its effect in water absorption of the final product and its addition limit, which must lead to water absorption value $\leq 6 \%$.

Figure 8 shows that porosity plays an important role in the bending strength. Open porosity due to irregular shaped elongated pores decreases the bending strength, in contrast, spherical pores formed at higher temperatures lead to relatively high strength. At optimum firing temperatures, the sintered bodies show bending strength values of 22 MPa for Astilleros, 19 MPa for Cuchia and 16 MPa for Raos sintered sediment. The values showed by Astilleros and Cuchia samples comply with the requirements of the European Standard EN 14411 [53], which propose bending strength values, as determined by the European Standard EN ISO10545-4 [54], of > 15 MPa and >20 MPa for covering and pavement ceramic tiles respectively. As for Raos sediment, the sintered specimen is conformed to the value proposed for covering tile but yet again, prior to its use as secondary raw material in a ceramic paste for pavement tile production it is necessary to determine its effect in bending strength of the end products.

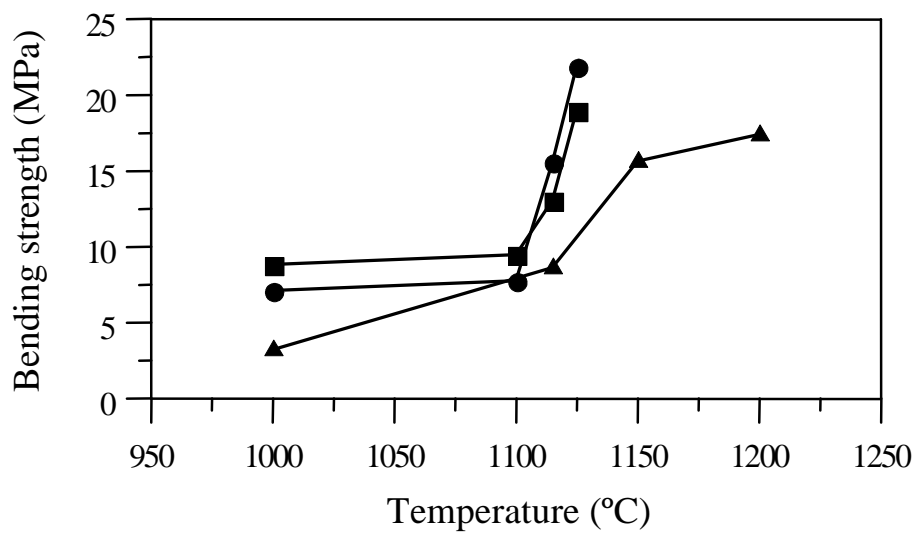

Figure 8. Bending strength as function of firing temperature in the $1000^{\circ}-1200^{\circ} \mathrm{C}$ temperature interval ( Astilleros; $\mathbf{\square}$ Cuchia; $\boldsymbol{\Delta}$ Raos).

Finally, Figure 9 shows the evolution of compressive strength with temperature for the three sediments investigated. At optimum firing temperatures, the sintered bodies show compressive strength values of $11 \mathrm{~N} / \mathrm{mm}^{2}$ for Cuchia and $34 \mathrm{~N} / \mathrm{mm}^{2}$ for Astilleros and Raos sediments. In this case, the three sintered samples comply with the value fixed by AENOR, which establishes a compressive strength value, as determined by the European Standard EN-772-1 [55], of $>10 \mathrm{~N} / \mathrm{mm}^{2}$ for high density traditional bricks. 


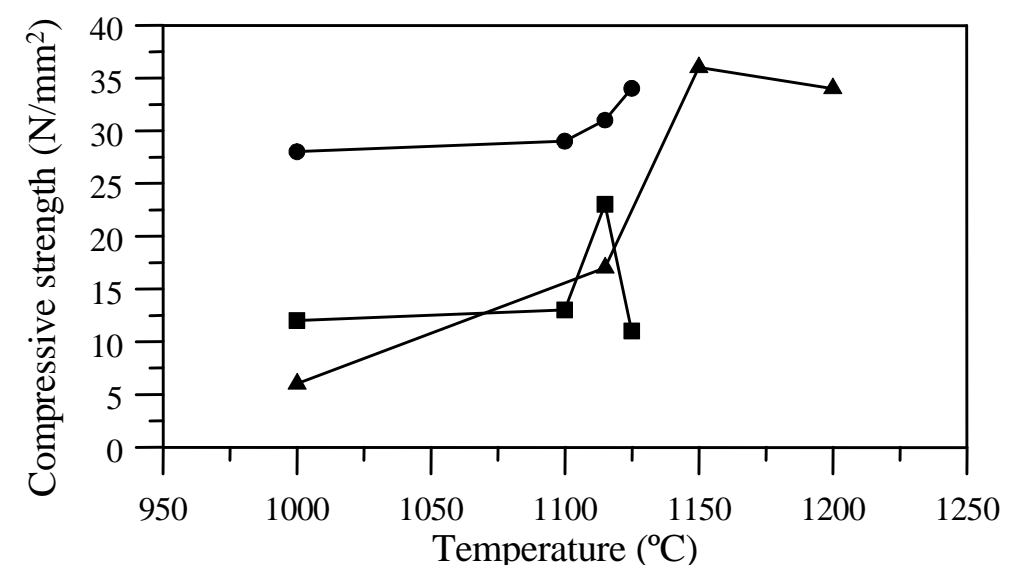

Figure 9. Compressive strength as function of firing temperature in the $1000^{\circ}-1200^{\circ} \mathrm{C}$ temperature interval Astilleros; $\mathbf{D C u c h i a ;} \boldsymbol{\Delta}$ Raos).

\section{Conclusions}

The present study has shown that it is possible to obtain dense sintered compacts from highly contaminated marine sediments dredged from the Santarder Bay and Suances estuary (Spain). The sintering behaviour of three marine sediments was studied in the $900^{\circ}-1200^{\circ} \mathrm{C}$ temperature interval for $1 \mathrm{~h}$. During the sintering process, the development of a liquid phase progressively causes a decrease in open porosity and water absorption, until minimum value is reached, while open porosity increases. With increase temperature, the gas pressure inside the closed pores causes a meaningful growth of their size. Water absorption and mechanical properties determined for Astilleros and Cuchia samples show that the specimens fired at their respective optimum sintering temperature met the requirement values established by different European Standards for high density traditional bricks, covering ceramic tiles as well as for the more demanding criteria to high density clinker bricks and pavement ceramic tiles. As for Raos sediments, its addition to a ceramic paste for clinker brick or pavement tile production requires a previous study to determine its effect in water absorption and bending strength of the end products.

Based on these preliminary analyses, it can be concluded that studied marine sediments can be used as secondary raw materials for the production of ceramic bricks and ceramic floor and wall tiles by powder technology.

\section{Acknowledgements}

This research was supported by the Spanish Education and Science Ministry (Projects CTM 2005-07282-C03/03 and CTM 2006-07960). The authors thank to C. Rivera from University of Castilla-La Mancha (Spain) for his experimental assistance in hot-stage microscopy. 


\section{References}

1. W. Salomons, Long-term strategies for handling contaminated sites and large-scale areas, in W. Salomons and W. Stigiani (Eds.), Biogeodynamics of Pollutants in Soils and Sediments, Springer-Verlag, Berlin, 1995, pp. 1-30.

2. W. Calmano, W. Ahlf, U. Förstner, Sediments quality assessments: chemical and biological approaches, in W. Calmano, W. Ahlf, U. Förstner (Eds.), Sediments and Toxic Substances, Springer-Verlag, Berlin, 1996, pp. 1-35.

3. J. Brils, W. Salomons, Contaminated Sediments in European River Basins, SedNet Booklet, 2004, pp. 80.

4. P.M. Chapman, J. Anderson, A decision-making framework for sediment Contamination. Integrated Environmental Assessment and Management 1 (3) (2005) 163-173.

5. PIANC. 2006. Generic Biological Assess Guidelines For Dredged Material. Port International Association for Navigation and Commerce. Technical report work-group EnviCom 8.

6. OSPAR Commission. 2004. Revised OSPAR Guidelines for the Management of Dredged Material. Reference number: 2004-08.

7. T.A. DelValls, A. Andrés, M.J. Belzunce, J.L., Buceta, M.C. Casado-Martínez, R. Castro, I. Rib, J.R. Viguri, J. Blasco, Chemical and ecotoxicological guidelines for managing disposal of dredged material, Trends in Analytical Chemistry 23 (10-11) (2004) 819-828.

8. J. Viguri, J. Verde, A. Irabien, Environmental assessments of polycyclic aromatic hydrocarbons (PAHs) in the surface sediments of the Santander Bay, Northern Spain, Chemosfere 48 (2002) 157-165.

9. P. Rodriguez, J. Arrate, M. Martínez-Madrid, V. Schumacher, T.B. Reynoldson, J. Viguri, J., Toxicity of Santander Bay sediments to the eurihaline freshwater oligochaete Limnodrilus hoffmeisteri, Hydrobiologia 564 (2006)157-169.

10. C. Gonzalez-Piñuela, A. Coz, A. Andres, M.J. Irabien, I. Yusta, J.R. Viguri JR., PAHs composition in surface and core sediments from the Santander Bay (Northern Spain), Fresenius Environmental Bulletin 15 (2006) 1031-1036.

11. M. González-Antolin, C. González-Piñuela, A. Coz, A. Andres, J.R. Viguri, Extractable organic halogens (EOX) in estuarine sediments of Cantabria, Nothern Spain, in: Proceedings of the SedNet Working Packaje 3 Conference, 2004, p. 90.

12. M. Dondi, M. Marsigli, B. Fabbri, Recycling of industrial and urban wastes in brick production—a review, Tile and Brick International 13 (1997) 218-225.

13. A. Andres, N. Fernandez Gómez, S. Rivero Gutierrez, J.R.Viguri, Reusing of waste materials in ceramic: analysis of scientific-technical information, in: 10th Mediterranean Congress on Chemical Engineering, 2005. 
14. R. Caligaris, N. Quaranta, M. Caligaris and E. Benavidez, Materias primas no tradicionales en la industria ceramica, Boletín de la Sociedad Española de Cerámica y Vidrio 39 (2000) 623-626.

15. I. Demir, An investigation on the production of construction brick with processed waste tea, Building and Environment 41 (9) (2006) 1274-1278.

16. I. Demir, M.S. Baspinar, M. Orhan, Utilization of kraft pulp production residues in clay brick production, Building and Environment 40 (11) (2005) 1533-1537.

17. F. Cernec, J. Zule, A. Moze, A. Ivanus, Chemical and microbiological stability of waste sludge from paper industry intended for brick production, Waste Management and Research 23 (2) (2005) 106-112.

18. A. Weng, D. Lin, P. Chiang, Utilization of sludge as brick material, Advances in Environmental Research 7 (2003) 679-685.

19. M. Anderson, Encouraging prospects for recycling incinerated sewage sludge ash (ISSA) into clay based building products, in: Workshop on Novel Products from Combustion Residues, 2001, pp.313-324.

20. K.L. Lin, K.Y. Chiang, D.F. Lin, Effect of heating temperature on the sintering characteristics of sewage sludge ash, Journal of Hazardous Materials 128 (2-3) (2006) 175-181.

21. M. Anderson, R.G. Skerratt, The inclusion of alum-based waterworks sludge (WTR) in commercial clay building bricks. Tile and Brick International 19 (2003) 328335.

22. W. Acchar, F.A. Vieira, D. Hotza, Effect of marble and granite sludge in clay materials, Materials Science and Engineering 419 (2006) 306-309.

23. R.R. Menezes, H.S. Ferreira, G.A. Neves. Use of granite sawing wastes in the production of ceramic bricks and tiles. Journal of the European Ceramic Society 25 (2005) 1149-1158.

24. I. Blanco García, M. Rodas, C.J. Sánchez, M. Dondi, J. Alonso-Azcárate, Technological characterization and ceramic application of gravel pit by-products from middle-course Jarama river deposits (central Spain), Applied Clay Science 28 (1-4) (2005) 283-295.

25. A.M. Segadães, M.A. Carvalho, W. Acchar, Using marble and granite rejects to enhance the processing of clay products, Applied Clay Science 30 (1) (2005) 42-52.

26. R.R. Menezes, H.S. Ferreira, G.A. Neves, H.D. Lira, H.C. Ferreira, Use of granite sawing wastes in the production of ceramic bricks and tiles, Journal of the European Ceramic Society 25 (7) (2005) 1149-1158.

27. K.L. Lin, Feasibility study of using brick made from municipal solid waste incinerator fly ash slag. Journal of Hazardous Materials 137 (2006) 1810-1816.

28. A. Olgun, Y. Erdogan, Y. Ayhan, B. Zeybek, Development of ceramic tiles from, coal fly ash and tincal ore waste. Ceramics International 31 (1) (2005) 153-158. 
29. X. Lingling, G. Wei, W. Tao, Y. Nanru, Study on fired bricks with replacing clay by fly ash in high volume ratio, Construction and Building Materials 19 (2005) 243247.

30. J. Balgaranova, A.Petkov, L. Pavlova, E. Alexandrova, Utilization of wastes from the coke-chemical production and sewage sludge as additives in the brick-clay. Water, Air and Soil Pollution 150 (2003) 103-111.

31. C.R. Cheeseman, S. Monteiro da Rocha, C. Sollars, Ceramic processing of incinerator bottom ash, Waste Management 23 (2003) 907-916.

32. M. Dondi, G. Ercolani, G. Guarini, M. Raimondo, Orimulsion fly ash in clay bricks-part 1: composition and thermal behaviour of ash, Journal of the European Ceramic Society 22 (2002) 1729-1735.

33. M. Dondi, G. Guarini, M. Raimondo, I. Venturi, Orimulsion fly ash in clay brickspart 2: technological behaviour of clay/ash mixtures. Journal of the European Ceramic Society 22 (2002) 1737-1747.

34. J.W. Yoo, J.H. Jung, H.T. Kim, Synthesis and characterization of clay brick using coal wastes , Materials Science Forum 486-487 (2005) 403-406.

35. C.M.F. Vieira, P.M. Andrade, G.S. Maciel, F. Vernilli Jr, S.N. Monteiro, Incorporation of fine steel sludge waste into red ceramic. Materials Science and Engineering 427 (2006) 142-147.

36. P. Shih, Z. Wu, H. Chiang, Characteristics of bricks made from waste steel slag. Waste Management 24 (2004) 1043-1047.

37. F.J. Valle, E. Rivera, J.Ma. Rincón, Characterization of steel waste powder colourant for applications in brick manufacturing, La Revue de Metallurgie-CIT/ Science et Génie de Materiaux (mai) (1995) 681-68.

38. E.A. Dominguez, R. Ulmann, "Ecological bricks" made with clay and steel dust pollutants, Applied Clay Science 11 (1996) 237-249.

39. T. Kavas, Use of boron waste as a fluxing agent in production of red mud brick. Building and Environment 41 (2006) 1179-1783.

40. T.Uslu, A.I. Arol, Use of boron waste as an additive in red bricks. Waste Management 24 (2004) 217-220.

41. K. Hamer, A. Hadeler, T. Muschalla, J. Schro ter, G. Timmer, Light weight aggregates made from dredged harbour sediments: Leaching behaviour of inorganic pollutants and constructional characteristics, Journal of Soils and Sediments, 3 (4) (2003) 284-291.

42. K. Hamer, V. Karius, Brick production with dredged harbour sediments. An industrial-scale experiment, Waste Management 22 (5) (2002) 521-530.

43. A.G. Bernstein, E. Bonsembiante, G. Brusatin, G. Calzolari, P. Colombo, R. Dall'Igna, S. Hreglich, G. Scarinci, Inertization of hazardous dredging spoils, Waste Management 22 (2002) 865-869. 
44. V. Karius, K. Hamer, $\mathrm{pH}$ and grain-size variation in leaching tests with bricks made of harbour sediments compared to commercial bricks, Science of the Total Environment 278 (1-3) (2001) 73-85.

45. DIN 38414-S3, 1985. Determination of loss on ignition and residue on ignition of the dry matter of sludge. German standard method for the examination of water, wastewater and sludge. Sludge and Sediments. Part 3, Group S (S 3), 1-2.

46. W.E. Worrall, Clays and Ceramic Raw Materials, 2nd edition, Elsevier Applied Science Publisher, London, 1986.

47. M.B. Almendro, M.M. Jordán, J.Ma. Rincón, M.S. Hernández-Crespo, Eflorescencia en ladrillos, in: Materiales Inorgánicos en la Construcción para el Siglo XXI, Universidad Miguel Hernández, Elche, 2001, pp. 199-208.

48. S. Yariv, The role of charcoal on DTA curves of organo-clay complexes: an overview, Applied Clay Science 24 (3-4) (2004) 225-236.

49. S. Maitra, A. Choudhury, H. S. Das, Ms. J. Pramanik, Effect of compaction on the kinetics of thermal decomposition of dolomite under non-isothermal condition, Journal of Materials Science 40 (18) (2005) 4749 - 4751.

50. W.D. Kingery, Introduction to ceramics, J. Wiley \& Sons, New York, 1976, pp. 490-500.

51. EN-771. Specification for masonry unit. Part. 1. Clay masonry unit. Annex C. Determination of water absorption.

52. EN ISO 10545-3. Ceramic tiles. Part 3. Determination of water absorption, apparent porosity, apparent relative density and bulk density

53. EN 14411:2004. Ceramic tiles. Definitions, classification, characteristics and making.

54. EN ISO 10545-4. Ceramic tiles. Part 4. Determination of modulus of rupture and bending strength.

55. EN-772-1 Methods of test for masonry unit. Part. 1. Determination of compressive strength. 